\title{
PENGEMBANGAN KEGIATAN KOKURIKULER DAN EKSTRAKURIKULER
}

\author{
Khusna Farida Shilviana \& Tasman Hamami \\ UIN Sunan Kalijaga Yogyakarta \\ 19204010010@student.uin-suka.ac.id, tasmanhamami61@gmail.com
}

\begin{abstract}
Development of cocurricular and extracurricular activities is important to do, because intracuricular activities are felt to be lacking in developing students' potential. Thus, the need for companion activities that can help maximize the potential of students. The purpose of this study was to investigate the development of cocuricular and extracurricular activities. This research uses library research method (library research). The results of the research on the development of cocurricular activities, namely in their activities, must lead to activities that support intracuricular activities and student learning interests, do not contain excessive burdensome burdens, and require administration, guidance or assistance, monitoring, and assessment. While the development of extracurricular activities through several stages including: 1) needs analysis which also aims to identify the needs, potential, and interests of students. 2) determine the type of extracurricular activities through tests, questionnaires, and interviews. 3) compile an extracurricular activity program. 4) implementation phase. 5) monitoring and evaluation phase. In the development of extracurricular activities, it is also supported by education unit policies, the availability of coaches, and the availability of educational unit facilities and infrastructure
\end{abstract}

Keywords: Development, Cocurricular, Extracurricular

\begin{abstract}
Abstrak: Pengembangan kegiatan korikuler dan ekstrakurikuler penting untuk dilakukan, karena kegiatan intrakurikuler di rasa masih kurang dalam mengembangkan potensi peserta didik. Sehingga, perlu adanya kegiatan pendamping yang bisa membantu memaksimalkan potensi peserta didik. Tujuan dari penelitian ini adalah untuk mengetahui pengembangan kegiatan kokurikuler dan ekstrakurikuler. Penelitian ini menggunakan metode studi pustaka (library research). Hasil dari penelitian pengembangan kegiatan kokurikuler yaitu dalam kegiatannya harus mengarah pada kegiatan yang menunjang kegiatan intrakurikuler serta kepentingan belajar siswa, tidak mengandung beban yang berlebihan yang memberatkan, serta perlu adanya administrasi, bimbingan atau pendampingan, pemantau, dan penilaian. Sedangkan pengembangan kegiatan ekstrakurikuler melalui beberapa tahapan diantaranya yaitu: 1) analisis kebutuhan yang juga bertujuan untuk mengidentifikasi kebutuhan, potensi, dan minat peserta didik. 2) menetapkan jenis kegiatan ekstrakurikuler melalui tes, kuesioner, dan wawancara. 3) menyusun Program Kegiatan Ekstrakurikuler. 4) tahap pelaksanaan. 5) tahap monitoring dan evaluasi. Dalam pengembangan kegiatan ekstrakurikuler juga di dukung oleh kebijakan satuan pendidikan, ketersediaan pembina, dan ketersediaan sarana dan prasarana satuan pendidikan.
\end{abstract}

Kata Kunci: Pengembangan, Kokurikuler, Ekstrakurikuler 


\section{PENDAHULUAN}

Pendidikan merupakan sebuah sarana dalam rangka untuk menumbuhkembangkan kemampuan individu supaya nantinya bisa menjadi individu yang mempunyai iman, taqwa, perilaku mulia, berpengetahuan, cakap, kreatif dan mandiri. Selanjutnya untuk mewujudkan itu semua dibentuklah yang namanya kurikulum. Kurikulum diartikan sebuah berkas yang didalamnya berisi rencana yang rinciannya berupa tujuan yang hendak dicapai, sejumlah materi serta berbagai pengalaman belajar yang seharusnya dikerjakan siswa, cara dalam mengembangkannya, evaluasi yang disusun dalam rangka untuk mengetahui sejauh mana pencapaian dari tujuan tersebut serta perwujudan nyata dari berkas yang telah di rancang tadi. ${ }^{1}$ Kurikulum ini terdiri dari kegiatan yang bersifat intrakurikuler, kokurikuler dan ekstrakurikuler.

Kegiatan intrakurikuler adalah suatu kegiatam dalam proses pembelajaran yang berhubungan dengan mata pelajaran dalam struktur kurikulum. Dalam pelaksanaannya kegiatan intrakurikuler ini di rasa masih kurang dalam perwujudannya mengembangkan potensi dalam diri peserta didik, misalnya saja dalam masalah pemberian jam mata pelajaran, dalam satu minggu satu mata pelajaran hanya diberikan jam pelajaran sebanyak satu, dua, dan paling banyak hanya tiga jam mata pelajaran dalam satu minggunya. Oleh karena itu, diperlukan adanya kegiatan pendamping yang bisa membantu untuk memaksimalkan potensi dalam diri peserta didik. Dan sekaligus sebagai tanggapan dari apa yang menjadi tuntutan kebutuhan dari masing-masing peserta didik, membantu ketika ada yang masih kurang, memperkaya lingkungan belajar agar tidak hanya itu-itu saja, serta memberikan wadah agar mereka bisa latihan supaya mereka lebih kreatif. Oleh karenanya, disinilah peran dari kegiatan korurikuler dan ekstrakurikuler.

Kegiatan korikuler adalah kegiatan yang dalam pelaksanaannya dilakukan di luar kelas serta jam pelajaran dengan tujuan membantu peserta didik dalam hal pendalaman serta penghayatan terhadap materi yang telah didapatnya dalam kegiatan intrakurikuler. ${ }^{2}$ Sedangkan Kegiatan ekstrakurikuler adalah program kegiatan yang

${ }^{1}$ Wina Sanjaya, Kurikulum dan Pembelajaran, (Jakarta: Kencana, 2008), 9-10.

2 Danang SB, Budaya Tertib Lalu Lintas, (Rawamangun: Sarana Bangun Pustaka, 2011), 63-64. 
dalam pelaksanaannya dilakukan oleh peserta didik yang berada di luar kelas dan di luar jam pelajaran (kurikulum) dengan tujuan untuk membantu dalam hal mengembangkan potensi Sumber Daya Manusia (SDM) yang dimiliki oleh peserta didik, baik itu yang berkaitan dengan pengaplikasian ilmu pengetahuan yang telah diperolehnya maupun dalam arti khusus untuk membantu peserta didik dalam hal mengembangkan apa yang menjadi potensi dan bakat dalam dirinya dengan melalui kegiatan-kegiatan wajib maupun pilihan. Dalam praktiknya, masing-masing dari pelaksanaan program kegiatan ekstrakurikuler yang ada di sekolah nantinya akan memberikan banyak manfaat, yang mana tidak hanya didapat oleh peserta didiknya tetapi juga terhadap efektivitas dalam penyelenggaraan pendidikan di sekolah. Pelaksanaan dari program kegiatan ekstrakurikuler merupakan salah satu bagian dari pengembangan institusi sekolah secara keseluruhan. ${ }^{3}$

Setiap sekolah mempunyai alasan agar kegiatan kokurikuler \& ekstrakurikuler dijadikan sebagai kegiatan pilihan di sekolahnya masing-masing, sehingga harapannya nanti setiap sekolah memiliki program yang beragam dan menarik bagi siswa. Oleh karenanya kiranya penting untuk mengetahui panduan-panduan dalam pengembangan kedua kegiatan tersebut agar nantinya tujuan yang ingin dicapai dari suatu pendidikan itu bisa tercapai secara maksimal. Untuk mengetahui lebih lanjut mengenai bagaimana pengembangan kegiatan kokurikuler \& ekstrakurikuler, dalam kajian ini akan membahas mengenai pengembangan kegiatan kokurikuler \& ekstrakurikuler.

\section{METODE}

Penelitian ini dengan menggunakan pendekatan studi pustaka atau library research. Dalam penelitian kepustakaan ini dilakukan dengan proses mengumpulkan, menganalisis, mengolah dan menyajikan buku, jurnal, dan teks-teks yang berkaitan dengan tema penelitian sebagai bahan referensi dalam bentuk laporan kepustakaan. ${ }^{4}$

${ }^{3}$ Sudirman Anwar, Management of Student Development (Perspektif al-Qur'an dan Sunnab), (Riau: Yayasan Indragiri, 2015), 46-47.

${ }^{4}$ Mestika Zed, Metode Penelitian Kepustakaan, (Jakarta: Yayasan Obor Indonesia, 2008), 1-2. 
Untuk selanjutnya menganalisis dengan melalui pendekatan reflektif thingking, yaitu sebuah gabungan antara pendekatan induktif dan deduktif.

\section{HASIL DAN PEMBAHASAN}

\section{Kegiatan kokurikuler}

\section{Definisi kegiatan Kokurikuler}

Kegiatan kokurikuler adalah suatu kegiatan yang merupakan bagian dari kegiatan sekolah yang pelaksanaannya di lakukan di luar jam pelajaran dengan tujuan agar membantu siswa dalam hal mendalami sekaligus menghayati berbagai materi yang nanti akan dipelajarinya ketika dalam kegiatan intrakurikuler. ${ }^{5}$ Sedangkan pengertian kokurikuler menurut beberapa pendapat yang lainnya adalah sebagai berikut: a) Kegiatan kokurikuler diartikan sebagai kegiatan yang dalam pelaksanaannya di luar dari jam pelajaran yang bisa juga dilaksanakan ketika waktu libur. ${ }^{6}$ Dalam praktiknya kegiatan ini dapat dilaksanakan baik di sekolah maupun luar sekolah, dengan mendasarkan pada tujuan yang tetap harus menunjang dari program kegiatan intrakurikuler. b) kegiatan kokurikuler merupakan program kegiatan yang dalam tujuan pelaksanaannya lebih mengacu kepada pendalaman serta penghayatan materi yang telah di dapat peserta didik dari kegiatan intrakurikuler yang berasal dari kegiatan yang ada di dalam kelas, baik yang di dapat dari pelajaran inti ataupun program khusus. ${ }^{7}$ Dalam praktiknya, kegiatan kokurikuler bisa berasal dari beragam kegiatan yang diantaranya yaitu: mendalami materi-materi terntentu, menyelenggarakan riset, mengerjakan makalah atau membuat kliping, majalah dinding, serta mempelajari keterampilan sehingga lebih bisa mendalami materi pelajaran. Dari kesemua kegiatan tersebut nantinya juga akan diperhitungkan ketika menilai mata pelajaran yang berkaitan. ${ }^{8}$

${ }^{5}$ Irwansyah, Pendidikan Jasmani, Olahraga, dan Kesehatan, (Bandung: Media Pratama, 2006), 208.

${ }^{6}$ Chomaidi dan Salamah, Pendidikan dan Pengajaran: Strategi Pembelajaran Sekolah, (Jakarta: Grasindo, 2018), 267.

${ }^{7}$ Burhan Nurgiantoro, Dasar-dasar Pengembangan Kurikulum Sekolah, (Yogyakarta: BPFE, 1988), 137.

${ }^{8}$ Chomaidi dan Salamah, Pendidikan dan Pengajaran: Strategi Pembelajaran Sekolah, 267. 


\section{Tujuan kokurikuler}

Dalam kegiatan kokurikuler terdapat beberapa tujuan yang nantinya bisa dijadikan sebagai acuan/pedoman mengenai pentingnya kegiatan kokuriler ini dilakukan sebagai penunjang dari kegiatan intrakurikuler. Berikut ini merupakan tujuan diadakannya kegiatan kokurikuler diantaranya yaitu sebagai berikut: a) Kegiatan kokurikuler bertujuan sebagai penunjang dari praktik program intrakurikuler dengan acuan utamanya peserta didik agar lebih menghayati materi yang telah di dapatnya serta melatih tanggungjawab peserta didik dalam menyelesaikan tugasnya. ' b) Kegiatan kokurikuler bertujuan untuk membantu peserta didik agar lebih mudah mempelajari sekaligus memahami materi yang nantinya baru akan dipelajarinya. ${ }^{10}$

\section{Bentuk kegiatan kokurikuler}

Beberapa contoh bentuk pelaksanaan kegiatan kokurikuler diantaranya seperti peserta didik diberikan tugas pekerjaan rumah baik tugas yang dikerjakan secara kelompok maupun perorangan. Misalnya: a) Pemberian tugas yang dikerjakan secara kelompok, dalam hal ini dilakukan dengan tujuan agar mengembangkan sikap gotong royong, saling menghormati, toleransi, kerja sama, sehingga kedepannya bisa membentuk peserta didik agar nantinya menjadi individu yang baik ketika nanti bermasyarakat. b) Pemberian tugas yang dikerjakan secara individu bertujuan lebih kepada mengembangkan minat serta kemampuan siswa agar siswa tersebut dapat mandiri. Contohnya seperti: mendalami materi-materi terntentu, menyelesaikan PR, serta bisa juga berupa kegiatan yang dikerjakan di luar sekolah ataupun dikerjakan di luar kampus. ${ }^{11}$

\section{Pengembangan kegiatan kokurikuler}

Dalam mengembangkan kegiatan kokurikuler harus memperhatikan asas-asas kokurikuler sebagaimana yang telah ditetapkan agar kegiatan kokurikuler ini bisa tepat sasaran. Diantara asas-asasnya yaitu sebagai berikut:

\footnotetext{
${ }_{9}$ Chomaidi dan Salamah.

${ }^{10}$ Irwansyah, Pendidikan Jasmani, Olabraga, dan Kesehatan, 210.

${ }^{11}$ Sulistyorini, Manajemen Pendidikan Islam, (Surabaya: eLKAF81, 2006), 81.
} 
a. Dalam pelaksanaan kegiatan kokurikuler diharuskan mengacu terhadap kegiatan yang menunjang langsung dengan kegiatan intrakurikuler serta kepentingan belajar siswa. Ini dimaksudkan agar nantinya siswa dapat lebih memahami serta mendalami materi yang telah diajarkan dengan lebih mudah.

b. Dalam pelaksanaan kegiatan kokurikuler tidak mengandung beban yang berlebihan yang berakibat memberatkan bagi siswa. Hendaknya dalam praktiknya kegiatan kokurikuler tidak terdapat kegiatan yang justru malah berlebihan yang nantinya malah memberatkan peserta didik itu sendiri. Itu berarti bahwa seorang yang membuat kegiatan kokurikuler hendaknya diatur dengan sebaik mungkin agar jangan sampai membuat kegiatan yang justru menciptakan beban yang berlebihan bagi peserta didik, baik beban itu berkaitan dengan beban mental maupun beban material. Hal tersebut harus dihindari karena demi menjaga agar peserta didik tidak tertekan, dan harusnya kegiatan kokurikuler ini disusun sedemikian rupa agar peserta didik merasakan manfaat dan merasa senang dengan adanya kegiatan kokurikuler ini dan tidak mengakibatkan beban pembiayaan yang bertambah berat bagi orangtua peserta didik.

c. Dalam pelaksanaannya perlu adanya administrasi, bimbingan atau pendampingan, pemantauan, dan penilaian. Hal tersebut diperlukan karena ketika seorang guru menyusun kegiatan kokurikuler misalnya seperti memberikan tugas, seorang guru seharusnya disertai dengan adanya administrasi yang baik misalnya berupa pemberian petunjuk yang jelas mengenai tugas-tugas tersebut, pencatatan yang juga teratur, memberikan bimbingan atau pendampingan. Hal tersebut menjadi penting untuk dilakukan dengan maksud membantu peningkatan dalam kegiatan kokurikuler supaya hasilnya nanti berlangsung dengan baik sesuai dengan tujuan yang telah ditetapkan. Penerapannya dalam kegiatan kokurikuler misalnya setiap kegiatan harus sudah terjadwal dengan baik, dan tak lupa dalam setiap kegiatannya seorang guru harus membimbing dan juga memeriksanya, untuk kemudian 
dilakukan penilaian dengan didasarkan pada panduan buku penilaian yang telah disusun sebelum kegiatan tersebut terlaksana. ${ }^{12}$

\section{Kegiatan Ekstrakurikuler}

\section{Definisi kegiatan ekstrakurikuler}

Ekstrakurikuler merupakan gabungan dari dua kata yakni ekstra dan kurikuler. Ekstra diartikan suatu hal yang ada di luar yang seharusnya untuk dilaksanakan, yang mana kedudukannya sebagai tambahan. Sedangkan kurikuler berhubungan dengan kurikulum, yaitu sebuah rancangan yang telah dipersiapkan oleh suatu lembaga pendidikan yang digunakan untuk mewujudkan berbagai tujuan yang telah ditentukan pada lembaga pendidikan. Menurut Badrudin, kegiatan ekstrakurikuler dimaknai sebagai sebuah perhimpunan yang telah disiapkan oleh satuan pendidikan dalam rangka untuk mengarahkan apa yang menjadi minat, bakat, kegemaran, kepribadian dan kreasi peserta didik sehingga nantinya dijadikan sebagai acuan dalam mendeteksi talenta peserta didik. Dalam praktiknya program yang telah disiapkan tersebut memuat rumusan rencana dan aturan-aturan yang berkaitan dengan tujuan, isi, materi pelajaran, serta tata cara atau strategi yang nantinya digunakan sebagai acuan dalam menyelenggarakan berbagai aktivitas pembelajaran dalam rangka mencapai tujuan pendidikan tertentu yang telah ditetapkan. ${ }^{13}$

Kegiatan ekstrakurikuler dimaknai juga sebagai program kegiatan yang dalam pelaksanaannya berada di luar jam belajar kurikulum yang standar, yang sekaligus sebagai penambahan dari program kegiatan kurikulum. Dalam pelaksanaannya program kegiatan ekstrakurikuler ini berada dalam bimbingan pihak sekolah dengan tujuan utama dari kegiatan ini mengacu pada pengembangan diri peserta didik dalam hal kepribadian, potensi, bakat, keinginan, serta kecakapan dari peserta didik yang lebih mendalam atau diluar yang telah dikembangkan dalam kurikulum. Semua kegiatan dalam program ekstrakurikuler merupakan kegiatan

\footnotetext{
12 Winarno Hamiseno, Petunjuk Pelaksanaan Pengelolaan Kurikulum, (Jakarta: Debdikbud, 1990), 27.

${ }^{13}$ Eca Gesang Mentari, dkk, Manajemen Pengembangan Pendidikan Anak Usia Dini Dilengkapi dengan Manajemen Perpustakaan dan Ekstrakurikuler, (Temanggung: Pustaka Indonesia, 2019), 103.
} 
yang dalam pelaksanaannya berada di luar dari jam pelajaran, yang bertujuan membantu dalam mewujudkan pengembangan potensi peserta didik. ${ }^{14}$

Kedudukan kegiatan ekstrakuriler bisa dikatakan sebagai fasilitas dalam membantu mengembangkan bakat serta apa yang menjadi kebutuhan dari peserta didik, yang mana kebutuhan dari peserta didik itu berbeda-beda. Baik yang berupa pengembangan dalam hal budi pekerti, sikap, bakat, maupun kreasi dari peserta didik. Oleh karenanya, dalam praktiknya kegiatan ekstrakurikuler perlu diadakannya penyusunan berbagai hal yang berkaitan dengan kegiatan ekstrakurikuler yang tertuang dalam kalender pendidikan oleh masing-masing satuan pendidikan. Namun, dalam pelaksanaan ekstrakurikuler di sekolah tidak lantas melupakan tujuan utama dari pembelajaran. Baik dalam pembelajaran maupun kegiatan ekstrakurikuler keduanya mempunyai tujuan utama yang sama yaitu membantu dalam peningkatan kecakapan dalam ranah kognitif, afektif, dan psikomotor dari peserta didik. ${ }^{15}$

Adapun dalam kegiatan ekstrakurikuler mempunyai visi yaitu untuk membantu mewujudkan pengembangan diri peserta didik dengan tetap disesuaikan pada apa yang menjadi kebutuhannya, potensi, bakat, serta keinginan masing-masing dari peserta didik melalui berbagai kegiatan khusus yang telah diadakan oleh pihak yang berkompeten di sekolah atau madrasah. Sedangkan misi yang ingin diwujudkan dari program kegiatan ekstrakurikuler adalah untuk menyediakan berbagai kegiatan yang nantinya bisa dipilih langsung oleh peserta didik dengan tetap berdasarkan pada apa-apa yang menjadi kebutuhan, potensi, bakat, dan keinginan dari peserta didik. Selain itu, juga untuk membantu dalam penyelenggaraan program kegiatan yang isinya memberikan beberapa peluang kepada peserta didik agar mereka lebih leluasa dalam mengeksplor dirinya dengan bebas melalui beberapa kegiatan mandiri atau kelompok yang telah disiapkan. ${ }^{16}$

14 Jasman Jalil, Pendidikan Karatker: Implementasi Oleh Guru, Kurikulum, Pemerintah dan Sumber Daya Pendidikan, (Sukabumi: CV Jejak, 2018), 129.

15 Jalil.130.

${ }_{16}$ Saihudin, Manajemen Institusi Pendidikan, (Ponorogo: Uwais, 2018), 109. 


\section{Fungsi kegiatan ekstrakurikuler}

Diantara berbagai fungsi dengan adanya kegiatan ekstrakurikuler yakni: a) Pengembangan, dari program ekstrakurikuler yang ada nantinya digunakan dalam rangka ikut mendukung dalam pengembangan individu peserta didik dengan melalui pendalaman minat, pengembangan potensi, dan pemberian peluang dalam rangka mewujudkan pembentukan karakter serta pelatihan kepemimpinan. b) Sosial, yaitu program kegiatan ekstrakurikuler yang ada nantinya digunakan dalam membantu dalam mewujudkan pengembangan kecakapan serta rasa tanggungjawab sosial peserta didik. Dalam pengembangan program kompetensi sosial ini dilakukan dengan cara memberi peluang kepada peserta didik dalam memperluas pengalaman sosialnya, praktek kecakapan sosial, serta penghayatan terhadap nilai moral dan nilai sosial. c) Rekreatif, yaitu program kegiatan ekstrakurikuler yang ada nantinya digunakan juga untuk mewujudkan keadaan santai, membahagiakan serta memuaskan peserta didik ketika dalam menunjang proses pengembangan dirinya. Selain itu, dalam program kegiatan ekstrakurikuler atmosfer yang dimunculkan seharusnya lebih menantang dan lebih menarik bagi peserta didik. d) Persiapan karir, yaitu program kegiatan ekstrakurikuler yang ada seharusnya juga menunjang dalam mengembangkan kesiapan karir peserta didik, misalnya dengan melalui pengembangan kapasitas. ${ }^{17}$

\section{Tujuan dan manfaat kegiatan ekstrakurikuler}

Dalam pelaksanaannya kegiatan ekstrakurikuler mempunyai tujuan yang hendak dicapai, diantaranya sebagai berikut: a) Memperluas yang sekaligus juga mendalami pengetahuan serta kecakapan yang sesuai/sejalan dengan program kegiatan yang terdapat dalam kurikulum. b) Dapat membantu mehamamkan peserta didik dalam mengaitkan hubungan antar beberapa pelajaran. c) Untuk menjadikan dekat antara pengetahuan yang telah didapat dengan kebutuhan serta tuntunan masyarakat. d) Membantu peserta didik dalam mengarahkan apa yang menjadi bakat serta minatnya. e) Membantu melengkapi dalam membina manusia

17 Kemendikbud, Panduan Teknis Kegiatan Ekstrakurikuler di Sekolah Dasar, Jakarta: Kemendikbud, 2016), 6 . 
dengan seutuhnya. Selain itu, juga agar peserta didik lebih mendapatkan wawasan pengetahuan dan kemampuan yang lebih luas lagi dari apa yang dipelajarinya selama di kelas. Hal ini berarti bahwa, tujuan dari diadakannya kegiatan ekstrakurikuler adalah untuk menunjang program pembelajaran di sekolah maupun madrasah, yang mana untuk membantu agar peserta didik lebih mudah memahami dan mendalami pelajaran, serta mendukung demi mewujudkan apa yang telah menjadi tujuan yang ditetapkan baik yang telah ditetapkan dalam kurikulum yang ada di sekolah/ madrasah. ${ }^{18}$ f) Kegiatan ekstrakurikuler juga mempunyai tujuan untuk mengembangkan peserta didik berkaitan dengan kepribadian, potensi, bakat, keinginan, dan kecakapan peserta didik agar supaya lebih luas atau lebih dalam lagi di luar minat yang telah dikembangkan oleh kurikulum. $^{19}$

Sedangkan dalam pelaksanaan kegiatan ekstrakurikuler mempunyai manfaat diantaranya yaitu: a) Mengembangkan nilai-nilai karakter siswa. b) Meningkatkan perilaku sosial, emosional, dan prestasi sekolah. c) Sebagai bentuk keterlibatan orangtua dengan sekolah. d) Meningkatkan mutu sekolah melalui manajemen ekstrakurikuler. e) Sebagai ciri khas sekolah. f) Sebagai wahana pengembangan diri. g) Sebagai layanan khusus dalam pendidikan di sekolah. ${ }^{20}$

\section{Prinsip kegiatan ekstrakurikuler}

Dalam pelaksanaannya kegiatan ekstrakurikuler juga tetap disesuaikan dengan prinsip-prinsip yang ada. Diantara prinsip kegiatan ekstrakurikuler diantaranya yaitu: a) Prinsip individual, yaitu dalam pelaksanaan kegiatan ekstrakurikuler dengan mengacu pada kesesuaian terhadap potensi, bakat, dan keinginan masingmasing dari peserta didik. b) Prinsip pilihan, yaitu dalam pelaksanaan kegiatan ekstrakurikuler harus mengacu pada kesesuaian terhadap keinginan serta tidak ada unsur paksanaan dalam diri peserta didik. c) Prinsip keterlibatan aktif, yaitu dalam pelaksanaan kegiatan ekstrakurikuler harus mengarah kepada tuntutan keikutsertaan secara penuh oleh peserta didik. d) Prinsip menyenangkan, yaitu

${ }^{18}$ Rahmat Raharjo Syatibi, Pengembangan \& Inovasi Kurikulum, (Yogyakarta: Azzagrafika, 2013), 173-74.

19 Eca Gesang Mentari, dkk, Manajemen Pengembangan Pendidikan Anak Usia Dini Dilengkapi dengan Manajemen Perpustakaan dan Ekstrakurikuler, 104.

${ }^{20}$ Eca Gesang Mentari, dkk,. 105. 
dalam pelaksanaan kegiatan ekstrakurikuler diharuskan terbentuk situasi yang disukai serta menyenangkan bagi peserta didik. e) Prinsip etos kerja, yaitu dalam pelaksanaan kegiatan ekstrakurikuler harus mengarah kepada kegiatan yang menjadikan peserta didik lebih bangkit semangatnya dalam mengerjakan sesuatu dengan baik dan berhasil. f) Prinsip kemanfaatan sosial, yaitu dalam pelaksanaan kegiatan ekstrakurikuler yang dilakukan harus mengacu kepada kegiatan yang memberikan kepentingan masyarakat. ${ }^{21}$

Dalam pelaksanaan kegiatan ekstrakurikuler yang telah disusun seharusnya ini tidak menjadi tanggungjawab secara khusus beberapa pihak saja, melainkan harus mendapatkan perhatian khusus dari beragam pihak yang sekaligus terlibat baik secara langsung maupun tidak langsung dalam penyelenggaraan pendidikan, tidak hanya berbagai pihak yang berkaitan dengan satuan pendidikannya saja, melainkan juga pihak pemerintah yang mana berkedudukan sebagai fasilitator pendidikan. Selanjutnya, untuk mendukung pelaksanaan program kegiatan ekstrakurikuler perlu adanya beberapa pedoman, baik itu yang berkaitan dengan materi ataupun kegiatannya, sehingga nantinya program yang telah disusun itu bisa terlaksana sesuai dengan tujuan yang telah ditetapkan. Untuk mewujudkan itu semua, maka perlu adanya sebuah informasi berupa pedoman yang jelas berkaitan dengan arti, tujuan serta hasil yang diinginkan, peranan serta beberapa hambatan yang muncul dengan disertai informasi yang jelas. Nantinya diharapkan para pembina, pendidik, kepala sekolah, guru, siswa, serta berbagai pihak yang terlibat dapat membantu dalam pelaksanaan kegiatan ekstrakurikuler berdasarkan dengan tujuan yang telah ditetapkan. $^{22}$

\section{Bentuk kegiatan ekstrakurikuler}

Berikut ini merupakan macam-macam bentuk kegiatan ekstrakurikuler diantaranya yaitu: a) Kegiatan ekstrakurikuler wajib. Yaitu pendidikan kepramukaan yang dijadikan kegiatan ekstrakurikuler wajib dalam kurikulum 2013. Pendidikan kepramukaan ini ditujukan untuk peserta didik baik yang berada pada tingkatan SD/MI, SMP/MTs, sampai dengan tingkatan SMA/MA, SMK/MAK.

${ }^{21}$ Saihudin, Manajemen Institusi Pendidikan, 109-110.

22 Anwar, Management of Student Development (Perspektif al-Qur'an dan Sunnab), 49-51. 
Dalam pelaksanaannya, biasanya bisa juga bekerja sama dengan satuan pramuka setempat/terdekat dengan acuannya didasarkan pada pedoman Operasi Standar Pendidikan Kepramukaan sebagai kegiatan ekstrakurikuler wajib. b) Kegiatan ekstrakurikuler Pilihan. Yaitu program kegiatan ekstrakurikuler pilihan yang dalam pelaksanaannya diatur oleh satuan pendidikan sendiri dengan disesuaikan pada apa yang menjadi bakat dan keinginan dari peserta didik. Contoh kegiatan ekstrakurikuler pilihan diantarannya yaitu: pertama, krida selain kepramukaan diantaranya yaitu kegiatan Latihan Kepemimpinan Siswa (LKS), kegiatan Palang Merah Remaja (PMR), kegiatan Usaha Kesehatan Sekolah (UKS), kegiatan Pasukan Pengibar Bendera (Paskibra). Kedua, karya ilmiah diantaranya yaitu kegiatan ilmiah remaja (KIR), kegiatan penguasaan terhadap keilmuan dan kecakapan akademik, riset dan lainnya. Ketiga, latihan dalam pengolahan bakat dan minat, diantaranya yaitu pengembangan bakat dalam bidang olah raga, seni dan budaya, pecinta alam, jurnalistik, teater, TIK, serta rekayasa dan lainnya. Keempat, dalam bidang keagamaan misalnya pesantren kilat, pelatihan dakwah keagamaan, Baca Tulis al-Qur'an, retreat dan lain sebagainya. Kelima, bentuk kegiatan lainnya sesuai analisis kebutuhan sekolah. ${ }^{23}$

\section{Pengembangan kegiatan ekstrakurikuler}

Dalam pengembangan kegiatan serta pelaksanaan kegiatan ekstrakurikuler tanggung jawab serta wewenang penuh ada pada satuan pendidikan. Sehingga dalam pelaksanaan perlu adanya sebuah aturan dari satuan pendidikan yang mana dalam mengambil keputusannya diadakan melalui rapat satuan pendidikan yang juga melibatkan berbagai pihak. Selain itu, dalam pelaksanaannya harus didukung pula dengan adanya pembina, adanya sarana dan prasarana.

Sarana satuan pendidikan diartikan sebagai segala sesuatu yang dibutuhkan dalam rangka untuk membantu pelaksanaan proses pendidikan dalam satuan pendidikan yang bisa berupa kebutuhan fisik, sosial, dan kultural. Sedangkan dalam unsur prasarana diantaranya yaitu: gedung, prasarana dalam bidang

23 Trianto Ibnu Badar at-Taubany dan Moch. Tolchah, Desain Pengembangan Kurikulum 2013 di Madrasah, (Depok: Kencana, 2017), 355. 
olahraga, prasarana dalam bidang kesenian, serta prasarana penunjang yang lainnya. ${ }^{24}$

Berikut ini merupakan pola dalam mengembangkan kegiatan ekstrakurikuler. Yaitu sebagai berikut:

\section{Gambar 1 Pola Pengembangan Kegiatan Ekstrakurikuler}

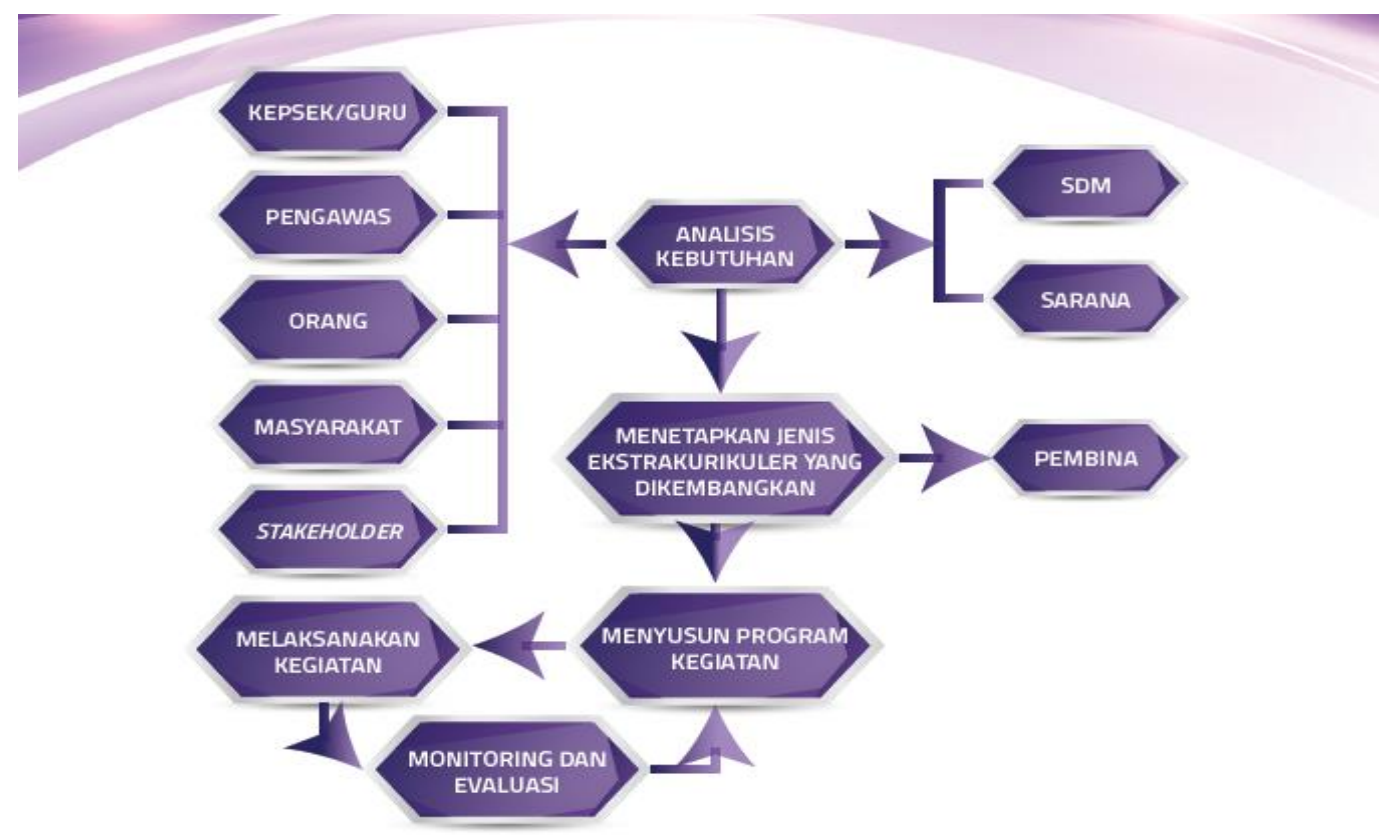

Sumber: Kemendikbud, 2016.

a. Analisis Kebutuhan

Tahapan awal yang seharusnya dilakukan oleh satuan pendidikan adalah dengan menganalisis apa yang menjadi kebutuhan dari kegiatan ekstrakurikuler. Dalam kegiatan ini, dengan melibatkan berbagai macam pihak diantaranya yaitu kepala sekolah, guru, pengawas, tenaga kependidikan, komite/orang tua atau pemangku kepentingan yang lainnya. Dalam kegiatan ini, menjadi penting dilakukan untuk menentukan apa saja yang menjadi kebutuhan serta keinginan

${ }^{24}$ Menteri Pendidikan dan Kebudayaan Republik Indonesia, "Salinan Lampiran Peraturan Menteri Pendidikan dan Kebudayaan Republik Indonesia Nomor 62 Tahun 2014 Tentang Kegiatan Ekstrakurikuler pada Pendidikan Dasar dan Pendidikan Menengah," t.t., http://gerbangkurikulum.psma.kemdikbud.go.id/wp-content/uploads/2016/09/Lampiran-PermenNomor-62-Tahun-2014.pdf. 
dari peserta didik, sarana apa saja yang telah dimiliki oleh pihak sekolah, serta kesiapan dari sumber daya manusianya, dan lain-lain. Selain itu, diperlukan juga dalam rangka untuk mengidentifikasi daya dukung yang telah dimiliki serta yang nantinya diperlukan pihak satuan pendidikan sebelum digunakan untuk menentukan berbagai macam kegiatan ekstrakurikuler.

Sedangkan diantara berbagai hal yang menjadi penting untuk menjadi perhatian ketika menganalisis kebutuhan yang berkenaan dalam mengembangkan kegiatan ekstrakurikuler diantaranya yaitu sebagai berikut: 1) merancang kembali beberapa program dari pengembangan ekstrakurikuler untuk selanjutnya menganalisisnya dengan beberapa kegiatan yang sudah ada untuk kemudian dicari apa yang menjadi kesenjangannya dengan kegiatan yang diinginkan. 2) merumuskan sasaran mutu yang ingin dicapai untuk kemudian melakukan analisis terhadap kepengelolaan dalam masing-masing unit kegiatan. 3) menentukan apa saja yang menjadi faktor yang mendukung serta faktor yang menghambat. 4) menerapkan apa yang strategi dalam rangka untuk mewujudkan kegiatan ekstrakurikuler, misalnya seperti membina kerjasama internal dan kemitraan eksternal, pengembangan kapasitas, serta pemberdayaan terhadap sistem informasi. 5)mengadakan kegiatan penilaian secara terusmenerus dengan berdasarkan titik tolak yang jelas sehingga nantinya bisa melakukan perbaikan setelahnya. ${ }^{25}$

b. Menetapkan jenis kegiatan ekstrakurikuler

Ketika akan menetapkan jenis kegiatan ekstrakurikuler bisa dilakukan dengan cara menelusuri atau menyaringan terhadap apa yang menjadi potensi, keinginan, bakat, motivasi dan kecakapan peserta didik dengan tetap mempertimbangkan dari adanya kuota untuk peserta didik dalam masingmasing program kegiatan ekstrakurikuler yang nantinya akan dilaksanakan. Dalam kegiatan penyaringan ini bisa dilakukan dnegan beberapa cara diantaranya yaitu test, angket, wawancara/penawaran tertentu. Untuk selanjutnya, nanti sekolah juga akan melakukan pengelompokkan siswa dengan jumlah tertentu berdasarkan pada kuota siswa yang dianggap berhak untuk

${ }^{25}$ Kemendikbud, Panduan Teknis Kegiatan Ekstrakurikuler di Sekolah Dasar, 32-33. 
mengikuti jenis program kegiatan ekstrakurikuler yang nantinya akan dilaksanakan. Dalam tahapan ini, sekaligus akan ditentukan siapa-siapa saja yang nantinya akan menjadi pembina atau pelatih. Hal ini diperlukan dengan tujuan supaya dalam pendistribusian sumber daya manusia yang ada dapat dilakukan secara merata. ${ }^{26}$

c. Penyusunan program kegiatan ekstrakurikuler

Ketika akan mengembangkan program kegiatan ekstrakurikuler, masingmasing dari satuan pendidikan diwajibkan untuk melakukan penyusunan program kegiatan ekstrakurikuler yang mana kegitan tersebut juga bagian dari Rencana Kerja Sekolah. Dalam pengembangan penyusunan program kegiatan ekstrakurikuler harus tetap mengacu pada penggunaan dari sumber daya bersama yang terdapat dalam gugus/klaster sekolah. Dalam penggunaannya selanjutnya pemerintah provinsi maupun pemerintah kabupaten/kota memberikan fasilitas dengan tetap disesuaikan pada kewenangan dari masingmasing pihak satuan pendidikan. Selanjutnya, program kegiatan ekstrakurikuler yang sudah jadi kemudian disosilisasikan kepada peserta didik serta orangtua/wali murid pada setiap awal tahun pelajaran. Dalam penyusunan program kegiatan ekstrakurikuler, setidaknya memuat beberapa hal diantaranya yaitu: 1) penjelasan dan tujuan umum; 2) pendeskripsian dari masinh-masing jenis program kegiatan; 3) Pengelolaan; 4) Pendanaan; dan 5) Evaluasi. ${ }^{27}$

Dalam sumber lain disebutkan bahwa dalam menyusun program kegiatan ekstrakurikuler setidaknya terdapat beberapa hal diantaranya yaitu: 1) jenis kegiatan, tentukan satu dari berbagai jenis program kegiatan ekstrakurikuler yang akan dilaksanakan. 2) waktu kegiatan, sesuaikan dengan waktu yang dibutuhkan untuk melaksanakan program kegiatan ekstrakurikuler. 3) sasaran, yaitu tentukan siapa-siapa saja yang diharuskan untuk mengikuti program kegiatan ekstrakurikuler 4) rangkaian kegiatan, dalam menyusun rangkaian kegiatan juga harus sesuai dengan ketentuan jenis kegiatan yang akan

${ }^{26}$ Kemendikbud.33-34.

27 Menteri Pendidikan dan Kebudayaan Republik Indonesia, "Salinan Lampiran Peraturan Menteri Pendidikan dan Kebudayaan Republik Indonesia Nomor 62 Tahun 2014 Tentang Kegiatan Ekstrakurikuler pada Pendidikan Dasar dan Pendidikan Menengah." 
dilaksanakan. 5) tempat kegiatan, bisa dilaksanakan di sekolah ataupun madrasah atau bahkan tempat yang lainnya. 6) peralatan yang digunakan, dalam hal ini disesuaikan dengan karakter dari jenis kegiatan yang nantinya akan dilaksanakan. 7) pelaksana, yaitu bisa saja berupa pelaksana yang utama serta pihak-pihak yang lainnya yang ikut terlibat di dalamnya. 8) pengorganisasian kegiatan, hal ini juga disesuaiakan dengan karakteristik dari jenis kegiatan ekstrakurikuler yang akan dilaksanakan. 9) anggaran, yakni dana yang diperlukan dalam semua kegiatan yang telah direncanakan. ${ }^{28}$

d. Pelaksanaan

Dalam menetukan pelaksanaan dari program kegiatan ekstrakurikuler, harus di atur supaya tidak bertentangan atau menjadi hambatan dalam pelaksanaan dari program intrakurikuler dan juga kokurikuler. Dalam merancang jadwal kegiatan ekstrakurikuler dilakukan oleh pembina yang mana mendapat arahan langsung dari kepala sekolah /madrasah maupun wakil kepala sekolah/ madrasah yang dilaksanakan di masa awal tahun pelajaran.

Dalam pelaksanaan program kegiatan ekstrakurikuler, setidaknya terdapat beberapa hal diantaranya yaitu: 1) nama kegiatan, hal ini disesuaikan berdasarkan susunan dari program kerja yang telah dilakukan sebelumnya. 2) mengadakan berbagai perlengkapan dan peralatan yang dibutuhkan dengan tetap disesuaikan pada masing-masing tahapan kegiatan. 3) pengadaan pelaksana kegiatan. 4) kegiatan awal, dalam hal ini kegiatan dilakukan lebih kepada persiapan peserta didik untuk melaksanakan kegiatan inti. 5) kegiatan inti, yaitu disesuaikan dengan inti yang ingin dicapai dalam tujuan kegiatan tersebut. 6) kegiatan akhir. 7) penilaian, yaitu menilai hasil akhir dan beberapa proses penyelenggaraan dari masing-masing tahapan pelaksanaan kegiatan. Proses dan mutu dari apa yang telah dicapai peserta didik berkaitan dengan kegiatan yang dimaksud. ${ }^{29}$

${ }^{28}$ Kemendikbud, Panduan Teknis Kegiatan Ekstrakurikuler di Sekolah Dasar, 36.

${ }^{29}$ Kemendikbud.37-38. 
e. Monitoring dan Penilaian

Sesuai dengan hasil dari monitoring serta evaluasi yang telah dilaksanakan pada tiap-tiap semester, selanjutnya satuan pendidikan berhak menambah atau bahkan mengurangi ragam kegiatan yang dilakukan dalam ektrakurikuler sehingga dapat dijadikan acuan dalam memperbaikan pedoman program kegiatan yang akan diberlakukan untuk tahun ajaran berikutnya. Dalam memonitoring serta mengevaluasi program kegiatan ekstrakurikuler, ada beberapa tahapan yang harus dilakukan sebelumnya, yaitu sebagai berikut: 1) menyusun beberapa program evaluasi. 2) mengadakan beberapa informasi yang di dapat dari beragam sumber yang ada kaitannya dengan apa yang telah direncanakan serta penerapannya dalam program. 3) melakukan analisis terhadap aspek apa saja yang berhubungan dengan faktor-faktor yang menunjang keberhasilan serta kegagalan dalam mencapai program yang dituju. 4) rekomendasi yang beragam disesuaikan dengan dilaksanakannya waktu evaluasi. Apabila evaluasi dilakukan pada masa awal kegiatan, nanti hasilnya bisa dijadikan masukan atau saran mengenai faktor apa saja yang menjadi kesulitan serta penghambat dalam penerapan program kegiatan. Manakala evaluasi dilakukan pada tengah-tengah kegiatan, nanti hasilnya bisa dijadikan masukan serta perbaikan dalam pelaksanaan program. Ketika evalusi dilaksanakan pada masa akhir kegiatan, nanti hasilnya dapat dijadikan pembelajaran sekaligus masukan dalam perencanaan program mendatang.

Selain itu, dalam program kegiatan ekstrakurikuler nantinya juga diadakan penilaian terhadap peserta didik berkaitan dengan kinerjanya ketika mengikuti program kegiatan ekstrakurikuler yang pelaksanaannya dilakukan secara kualitatif. Dalam penentuan indikator keberhasilan peserta didik didasarkan pada proses serta keikutsertaan peserta didik. dalam program kegiatan ekstrakurikuler wajib masing-masing peserta didik harus memperoleh nilai yang memuaskan. Sedangkan dalam program kegiatan ekstrakurikuler pilihan, penilaian terhadap peserta didik tertuang dalam buku rapor. Dan 
indikator penilaiannya didasarkan pada keikutsertaan serta prestasi peserta didik dalam mengikuti masing-masing program kegiatan ekstrakurikuler. ${ }^{30}$

\section{KESIMPULAN}

Dalam mengembangkan kegiatan korurikuler di sekolah, baiknya mengetahui bagaimana konsep-konsep dari kegiatan korikuler itu sendiri. Kegiatan kokurikuler yaitu program kegiatan yang dalam pelaksanaannya diadakan di luar jam pelajaran seperti biasa, sekaligus sebagai penunjang dari program intrakurikuler sehingga harapannya nanti pemahaman peserta didik terhadap materi pelajaran bisa lebih mendalam, sekaligus peserta didik agar terlatih untuk bertanggung jawab dalam menyelesaikan tugasnya. Sedangkan dalam mengembangkan kegiatan kokurikuler harus memperhatikan beberapa hal, diantaranya yaitu: 1) harus mengacu pada kegiatan yang bisa menunjang langsung dengan kegiatan intrakurikuler serta apa yang menjadi kepentingan belajar dari peserta didik. 2) tidak adanya beban yang berlebihan yang nantinya justru akan memberatkan bagi peserta didik. 3) perlu adanya administrasi, bimbingan atau pendampingan, pemantauan, dan penilaian.

Sedangkan dalam pengembangan program kegiatan ekstrakurikuler yang ada di sekolah, biasanya dilakukan melalui beberapa tahapan diantaranya yaitu: 1) analisis kebutuhan yang juga bertujuan untuk mencari tahu apa yang menjadi kebutuhan, potensi, dan minat dari masing-masing peserta didik. 2) menetapkan beberapa jenis kegiatan ekstrakurikuler dengan perantara tes, angket, dan wawancara. 3) menyusun berbagai program kegiatan ekstrakurikuler. 4) tahap pelaksanaan. 5) tahap monitoring dan evaluasi. Dalam pengembangan kegiatan ekstrakurikuler juga di dukung oleh aturan-aturan yang dibuat oleh satuan pendidikan, adanya pembina, serta adanya sarana dan prasarana satuan dari pendidikan.

${ }^{30}$ Kemendikbud.38-40. 


\section{DAFTAR PUSTAKA}

Anwar, Sudirman. 2015. Management of Student Development (Perspektif al-Qur'an dan Sunnah). Riau: Yayasan Indragiri.

Chomaidi, dan Salamah. 2018. Pendidikan dan Pengajaran: Strategi Pembelajaran Sekolah. Jakarta: Grasindo.

Danang SB. 2011. Budaya Tertib Lalu Lintas. Rawamangun: Sarana Bangun Pustaka.

Eca Gesang Mentari, dkk,. 2019. Manajemen Pengembangan Pendidikan Anak Usia Dini Dilengkapi dengan Manajemen Perpustakaan dan Ekstrakurikuler. Temanggung: Pustaka Indonesia.

Hamiseno, Winarno. 1990. Petunjuk Pelaksanaan Pengelolaan Kurikulum. Jakarta: Debdikbud.

Irwansyah. 2006. Pendidikan Jasmani, Olahraga, dan Kesehatan. Bandung: Media Pratama.

Jalil, Jasman. 2018. Pendidikan Karakter: Implementasi Oleb Guru, Kurikulum, Pemerintah dan Sumber Daya Pendidikan. Sukabumi: CV Jejak.

Kemendikbud. 2016. Panduan Teknis Kegiatan Ekstrakurikuler di Sekolah Dasar. Jakarta: Kemendikbud.

Menteri Pendidikan dan Kebudayaan Republik Indonesia. "Peraturan Menteri Pendidikan dan Kebudayaan Republik Indonesia Nomor 81A Tahun 2013 TentangImplementasiKurikulum,"t.t.https://www.google.com/url?sa=t\&sour ce=web\&rct=j\&url=https://luk.staff.ugm.ac.id/atur/bsnp/Permendikbud81A 2013ImplementasiK13Lengkap.pdf\&ved=2ahUKEwjKp9GckMzoAhVHILcA HUt5AoMQFjABegQIBBAB\&usg=AOvVaw14r_CnIQx24GFEE0RQ1vY_.

Nurgiantoro, Burhan. 1988. Dasar-dasar Pengembangan Kurikulum Sekolah. Yogyakarta: BPFE.

Saihudin. 2018. Manajemen Institusi Pendidikan. Ponorogo: Uwais.Sanjaya, Wina. 2008. Kurikulum dan Pembelajaran. Jakarta: Kencana.

Sulistyorini. 2006. Manajemen Pendidikan Islam. Surabaya: eLKAF81.

Syatibi, Rahmat Raharjo. 2013. Pengembangan \& Inovasi Kurikulum. Yogyakarta: Azzagrafika.

Taubany, Trianto Ibnu Badar at-, dan Moch. Tolchah. 2017. Desain Pengembangan Kurikulum 2013 di Madrasah. Depok: Kencana.

Zed, Mestika. 2008. Metode Penelitian Kepustakaan. Jakarta: Yayasan Obor Indonesia. 